\title{
VIII. Notes and observations on the remaining part of the Sixth and part of the Seventh chapters of Mr. Robert Bakewell's “Introduction to Geology;"-embracing incidentally, several new points of Geological investigation and theory
}

\section{Mr. John Farey Sen.}

To cite this article: Mr. John Farey Sen. (1814) VIII. Notes and observations on the remaining part of the Sixth and part of the Seventh chapters of Mr. Robert Bakewell's "Introduction to Geology;"-embracing incidentally, several new points of Geological investigation and theory, Philosophical Magazine Series 1, 43:189, 27-34, DOI: 10.1080/14786441408637963

To link to this article: http://dx.doi.org/10.1080/14786441408637963

曲 Published online: 27 Jul 2009.

Submit your article to this journal $₫$

山 Article views: 3

$Q^{\mathbf{2}}$

View related articles \lceil 


\section{$\left[\begin{array}{ll}27 & ]\end{array}\right.$}

VIII. Notes and Olservations on the remaining part of the Sixth and part of the Seventh Chupters of Mr. RoBert BaKewell's "Introduction to Geolugy;"embracing incidentally, several new Points of Ginlogical Investigation and Theory. By Mr. JoH N FAREY Sels., Mineral Surveyor.

[Continued from vol, xlii. p. 367 .]

$$
\text { Notes, } 80 \text {. }
$$

P.143, 1. 5, Loose stonest.-_+ Rubble, or angular broken stones, are never found in the Coal-measures, though such often are on, near the surface, in Coal-aclds, in common with almost every other part of the stony strata.

144, l. 1, narruwer or wider*,-

1. 10, the roof t. - + Rep. i. 345 .

1. 25, called tow \$.— \$ Tawe, Duns, \&c. Rep. i. 348.

$147,1.6$, raised on that side*._- But the Coal and other strata may, on the contrary, be sunk on that side, if the let-down is greater than the depth of the pit $g g$ : a case which not unfrequently happens, and such is evidently the source, of some of those grand mistakes, as to the identity of Cnal-seams, with which I have ventured to accuse even the most experienced Coalmasters and agents, Rep. i. 166 and 167, \&c. See my $2 d$ Letter, p. 110.

1. 22, shattered where they come in contact $f .-+$ See my Note on p. 208.

148,1 . 3, generally serve to identify it *... This defective rule, is often very improperly relied on, in speaking of the identity of Coal-seans (as observed in my ad Letter, p. 11 !), when far better evidence on this important point, might easily be had, by comparing the entire sinkings of the Pits, and tracing the bassets of the several strata on the surfuce, between the places.

1. 9, 300 yards t.- + Clandewa Coal Pits, SE of Paulton in Somersetshire, are reported to me, to be 400 yards deep!

1. 12, 30 feet $f .-t$ Rep. i. 176.

1. 21,13 feet thick***** Rep. i. 196.

149, 1. 9, Bind or Clunch*.- * White stone, Rep. i. 170, and Munt. Magy. v. xxi.

152, 1.25, one-third of Eisgland . - Which the Lias strata and those above it occupy, Rep. i. 116.

153, 1. 18, fonnderies *.* Furnaces, Rep. i. 395. 
P. 154, 1. 11, unfit to make iron *._* The second unsuccessful attempt with the Earl of Moira's Irou Furnace, on Ashby Wolds (Rep. i. 401), is here I suppose alluded to:-to me it seemed, when there on my Derbyshire Survey, that the quantily of iron-slone that could be readily got, was quite inadequate for the supply of the furmace erected. Earl Stanhope's fiarnace at Dale Abley (Rep. i. 397) is said to have failed, owing to the quality of the Coals in its vicinity, although the ironstone was in plenty, and of gond quality.

Noblenen and gcutlemen will in time find out, that they had much better take the advice of experienced professional Men, in the Letting of their Minerals on proper terms, than attempt the working of them on their own account; or, than take the first offer of any rash or inexperienced adventurers, who may apply.

$157,1.21$ and 22 , an alluvial production ${ }^{*}$ * This is certainly the case with a large proportion of our Wood Coal, ncar the surface, as that of Bovey (p. 158) mentioned in a Note in my first Lctier, p. 57. But it scems no less certain, that some irregular Coal-seams, having the characters of Wood Coal, are lodged between regular struta, that in particular, above the Doggers and alum Shale near Whitby in Yorks. mentioned page 267; which was working at Napehow in 1811 , and had formerly been wrought at Newton-house, Rudscar, \&c., P. M. Xxxix. p. 101 . The very irregular strata of wood Coal, above the Pipe Clay, in the Isle (as it is improperly called) of Purbcck, that are I believe alluded to P. M. xlii. p. 396 , I have not seen; but from the description by my oldest Son and others, who have seem them, I conclude them to belong to the alluyium. $161,1.22$, after each inundation*.- If the plants which gave rise to Coal, were all subaqueous, or adapted to the bottom of a deep and quiet Ocean, instead of dry land (as I suggested in the articles Coal and Colliery in Dr. Rees's (yclopædia), to which I know no opposing facts, but many coroborative oncs (Mont. Mag. xxxii. p. 514 and 515), all the difficulies, of Mr. B's almost infuitely repeated, alternations of dry Land and Water, would be avoided.

Mr. B. has no where noticed the important Geological fact, which I have generalised, I think (and was also the first writer who mentioned it, I believe) of the flours of Coal-seams, being all of one nature, viz. in- 
[P.161] fusible Clay, Rep. i. 179§; and also have shown, that the extinct Coaly vegetalles, in this respect, differ essentially from our Bog Plants, or such as have formed Peat, which seem to require a senaly soil for thcir growth, Rep. i. 308 and 319.

Besides the mere thin hollow pipes, or thin flat leaves, which distinguish the plants of the regular Coal strata, the British Strata throughout their whole series, almost, present in places, numerous detached specimens of the solid or ligneous parts of vegetables, closely resembling $W$ ood, iw hich sometimes, though rarely, are found with the bark on them, (but never with Roots, any more than the Coal plants, ) and more rarely with arms or main branches, but without any of the minuter branches or leaves : by far the greater number of specimens of this fossil Wood, whether petrified, carbouated, or rotten, are found in splinters or billcts, as if, first forcibly rent from large trees, and afterwards, for a long time foated in water, where they have become worm-eaten, and much worn, in many instances.

These circumstances attending fossil Woods, have greater difficulties attending them, than almost any of the Geological phænomena that I am acquainted with; - when and where did they grow?, how were they so generally rent? and so universally, and through such long periods of time, diffused in the original Ocean? \& $c$. I have been able to perceive no reasons, why the bottom of the primitive Waters may nnt have produced ligneous as well as less solid vegetables, where neither of such might require Roots (for such I believe are never found) to support them, owing to the quiet state of the waters, or to nourish them, any more than the corallines of our days.

162, 1. 7, may have consolidated*, - * Mr. B. has scarcely taken any notice in his work, of the kind of crystallization, by which seans or strata of Conal, are almost invariably found split (or capable of heing so), into rhomboidal biocks, by nearly vertical joints; the length-way joints being very generally called slines, and the oblique and shorter end-joints, called cutters, (see Note on page 69): nor has he noticed, a curious

In addition to eight or nine different Names, which I had found established, in different districts of Grcat Britain, for the infusible (lay, thus forming the floors of their severul Coal-seams, I lately met with the term Warrent, in the Isle of Anglesea, as the general name far the substance and stratum, immediately below each of their Coals.

fact, 
[P.162] fact, mentioned by me, Rep.i, 181 and 343, that theses lines very generally, if not invariably?, range abont ESE and WNW, through extensive districts, where the dips vary much, both locally and generally!

1. 14, the complete consolidation $\uparrow .-\uparrow$ See my Note on page 19.

166, 1. 22 and $z 3$, nearly horizontal *..* In a north and south direction, but having a very perceptible dip to the Eastward, Rep. i. 156, 168.

$167,1.1$, singularly contorted *.- * Mr. B. seems here to allude to the Wild-Park, Brcedon and Clouds-bill, magnesian and contorted Limestone Rocks, as being identical with the yellow Lime Rock, which overlies the Notts, Derby, York and Durham Coal-feld (see my Note on p. 176); notwithstanding, that they are herein, at pages 284,275 , \&c., represented to be identical with, and a continuation of, the Peak Limestones, and also with the shale Limestone near Ashburne, page 280 , which last, as clearly underlie this vast series of Coal strata, as mentioned in my second Letter, p. 106.

1. 12, quantity of common lime $+\ldots+$ Rep. ii. 107, 409 and 412 .

1. 23 , edifics in the metropolis +. - + The fine $\mathrm{Oa}$ lite stone, of the vicinity of Bath, is now coming into use in London, brought by the Kenmet and AvonCanal ; the stone using in restoring Henry VII's Chapel at Westminster, is from thence; and in an adjoining Field, my friend Mr. Wm. Smith has extensive quarries, and a rail-way thence to the Canal, where he has a Sawmill at work, preparing it for all the different purposes of the London Mason.

$168,1.9$, as has been traced*.- $*$ See the articles Coal and Colliery, in Dr. Rees's Cyclopadia, and Rep. i. 109.

1. 12 and 13, occur in the South t.- + Phil. Mag. $\mathrm{xxxix}$. p. 94.

1. 23, south of Europe 1 The Rev. J. Townsend, who was so well acquainted with our Chalk strata, before he travelled in Spain, and on his return, was not likely to mistake Mr. B's (" imaginary") earthy lime-stone, for chalk (see p. 185), nor is it probable, that the Island of Crete or Candia, and others in the south of Europe, are without Chalk, as Mr. B. has here insinuated; perhaps this doubt was expressed, in order to invalidate the suggestion alluded to at the conclusion of my Note on page 138.

P. 169, 
P.160, 1. 7, upper or soft Chalk *-_* P. M. xxxv. p. 130, and Rep. i. 111.

1. 20 , called chert †. - Rep. i. 272 .

171, 1. 23, lime and flint are changed*._* Rep. i. 272, and 415 : in Notes on my Paper on the Ashover Denudation, mentioned in a Note in my frst Letter (p. 5.5), several instances are mentioned, and the circumstances stated, under which such or similar changes appear to me to have happened, to different substances, when lodged in the alluvium : to the Slate Rubble on Whittle Hill in Charnwood Forest, for instance, see my Note nn Mr. B. p. 291.

172, 1. 13, layers of flint*-—* P. M. xxxv. p. 130, and Rep. i. 112.

1, 19 and 20 , building-stones $\uparrow .-†$ Totternhoe, Reche, and Ryegate stone, \&c., Rep. i. 112.

1. 24 and 25 , last or uppermost $1 .--\downarrow$ That Chalk is not the uppermost regular stratum in England, is now very evident, in the northern part of the Isle of Wight, Mr. B. p. 177 and 335 , P. M. xli. p. 224, and 461, vol. $x \times x y$. p. 132 , and vol. $x$ lii. p. 395 .

1. 25, alluvial ground **.- - The doubts formerly of my friend Mr. Benjamin Bevan, and others, as to the London Clays and Sinds being regular strata, P.M. $\mathbf{x x x v}$. p. $137 \S$, should I think be entirely removed, by the subsequent excavations in Highgate Hill and under Hyde Park, \&c. My worthy friend Mr. William Atkinson, Architect, of Bentinck Street, has also successfully investigated the nature of the Chert Nodules, which principally gave rise to the douhts alluded to, by collecting great numbers from the Gravel Pits and Roads near London, and causing them to be sawn through and polished:- they almost invariably prove

$\$$ At page 182 of the volume here referred to, I stated six different suggestions, in the form of queries, regarding the identity of the London and the Paris strata; the fourtb of these, on which there is a note at the bottom of the page, relates to a modified or altered nature of these strata (such as is mentioned of Red Marl and of Linestone Shale, Rep. i. 148, and 228; of Gritstones and of Coals, in my Notes on Mr. B's pages 44, 125, \&c. \&c. ; and wheren, an Offer in one of the Societies to whom 1 recommended the consideration of this question, has lately mentioned, the probability, that the blue Clay of Lundon and the culcuire grossier or coarse Limestone of Paris are parts of the same deposit or stratum, "and that from local circumstances the clay has prevailed in the ore, and the calcareou matter in the other," P. M. xlii. p. 398 .

At the battom of page 136, vol. sxxv. I suggested, that the Selenite of the London Clay (as in the Croydon Canal on Plow-Gaskic Hill SSW of Deptford), nay answer to the Gypsum of the neighbourhood of Paris. 
[P.172] of a concentric or nodular formation, and contradict the supposition, of their being rounded masses of flint, chert, or any otber stont: a small shell, proves the nuclens of one of the Nodules : in great numbers, the figures or stripes, curved, fortification-shaped, \&c. are very beautiful, and the colours quite equal to most of those which are washed out of the alluvial rul Clay on the shore near Whitby in York NR. and are collected from the beach with such avidity, by the $\mathrm{Cu}$ rious, many of whom are not aware, that they might find such at their own doors, near London. Mr. Sowerby's collection has long been rich, I believe, in these small nodular masses, of the London Clay strata. 173, 1. 3, extensive Lakes *.- See my Notes on p. 60, 138 and 182 , \&c.

1. 17, others foliated.+++ The specimens of Paris Gypsum, containing Bones, which I have seen, corresponded in their characters with none of the abnve, being earthy and slightly granular; intermediary in structure between Chalk and soft Oalite Limestone.

$174,1.26$, well-educated geognost *. - Sec page 176 Note, 353 Note, and Rep. i. xlvi.

$175,1.15$, morle and gravel containing *. $*$ The organic Remains here mentioned, all occur in Allavial Clay, on the Marle or Gypsum and not in the Red Marle, here or elsewhere, see Rep. i. 136 and 149 , Edinburgh Encyclopedia iii. 393, and my second Letter, p. 105.

$176,1.3$, The Geological situation *..* On first reading the paragraph which thas commences, and Mr. B's Note thereon, below, I could not help thinking, that he was attempting a hoax, on the "well educated geognosts," and I was unwilling to suppose, that he was bimself serious, in adding to the extreme confusion on this bead, with which be charges "the disciples of Werner" in his note on page 174 ; the point is howevcr of tou much importance, as to the real succession of the strata in England, to be thus dismirsed, and I will quote Mr. B's passage, with such references or explanations in [] as appcar to me necessary, viz.

"The Geological situation of the Derbysinire gypsum may be represented, as situated in the upper secondury strara, separated [below] from the mountain lime [i. e. transition L. p. 92, 93, Map p. 255 \&c.], by intervening coal districts on one side, atd [above] from the stratified magnesian lime [which is an upper 
Mr. Farey's Notes on Mr. Bakewell's Geology. 33

$[P .176]$ secondary rock, $\mathrm{p} .166]$ by sandstone on the other side."

Now it is evident, from page 166, although the mention of Derbyshire is omitted in describing the magnesian range, from Nottinghamshire to Northumberland, that the lower yellow Lime Rock, is here intended, and that the sandstone mentioned above, must mean the stratum next under the lower yellow Lime, (often appearing as a Sand, but sometimes also as a thick Sandstone Rock, see Rep. ii. p. 410, Note); because, otherwise, either Coal strata would occur on both sides of [above and below] his Gypsum if placed lower, or if Mr. B. referred to the upper yellow lime, and made his Gypsum belong to the intervening Red Marl, which I have lately traced between these rocks (P. M. xxxix. p. 104), then " earthy limestone" would occur [below] on one side of it instead of Coal strata; and thus therefore it should seem, that Mr. B. would persuade "the disciples of Werner," to place the Chellaston Gypsum, and its incumbent Red Marl, next above the Derbyshire Coal-measures, and under the yellow Lime Rock, which covers them!-.But has any Collier, sinking through the Limestone to work the Coals below, (as several do) ever seen an ounce of Gypsum?, or has such anywhere been found at its basset?, or even Red Marl, which might contain it ? .

What the sandstone (or Gravel Rock, Rep. i. 132) west of Nottinghan, has to do with the Gypsum of Chellaston Hill, in Mr. B's Note, p. 176, might puzzle a much better educated Geoguost, than 1 pretend to be.

1. 12 and 13 , in the gravel and marl.,-1 Marl has bere been inserted by mistake, see my 2nd Letter (p. 105) and note on page 175 .

1. 15 , a distinct formation $1 .-+$ The mistake on which this supposition is founded, is pointed out as above, see Rep.i. 147.

177, 1. 3, nver chalk*..* When the principles and practice of Mr. Wolliam Smith and others, in exploring and tracing the stratr, shall be extended to the Continent, which hitherto has very imperfectly been the case, as it would appear, from the large Map of the strata around Paris which was lately published, the calcareous strata here alluded to, and doubless many others above them in the series, will, I think, be very extcnsively traced, in connection, as well as seen in isoVol. 43 . No. 1S9. Jan. 1314. 
[P.177] lated hummocks, beyond their regular edges; see my note on page 336.

1. 8 , upper part of the Clay t. - + See my note on page 16.

i. ig, fresh-water shellst.- $\downarrow$ See my note on page 60 . 179. 1. 6, seas of salt and fresh water *... The Parisian Geologists speak nnt of Seas, but of Lakes of fresh water, I believe, and which are sufficiently improbabie, see P. M. xxxv. p. 134, and my note on page 18 ?. $131,1.21$, in their present situations *..* It has I hope been unintentional, that the true situation of the rcmains oi large Qluadrupeds near Paris, has, both here and at page 336 (No. 13), been omitted; although they are so expressly described, by M. Cavier and his associates (sce P. M. xxxv. p. 58), to be found in the most recsnt alluvium, and not in the stratified Clay beneath, as has in so many places here, been mistakingly represented, with respect to similar Remains, found near London: see my Note on page 16.

Sir Instph Banks has pery frequently mentioned to his friends, this idea (ascribed by Mr. B. to La Metherie), as to the Bones of large Quadrupeds, and Shells, supposed to be of fresh-water origin, found with them, having been drifted from the Land, by inundations; and he has referred to the situations of the two most noted depositaries of them near London; just below the junctions of the Brent and of the Roding Valleys, with the larger one of the Thames, near to Brentford and to Barking, as presenting probable reasons for their accumulation in these particular spots, by eddies in the meeting currents. Soon after the period of these depositions, it appears to me, that a comparatively quiescent state of the inundation recurred, and the alluvial deposit of loam or Brick-earth, so plentifully found upon the London Gravel, took place, and covered, and bas preserved these Bones, \&c.

$182,1.4$, of the great rivers *.- But where do great Rivers, or Lakes supplied by them, deposit regular strata? or any thing which can be mistaken for such strata, when examined with scientific attention?

[Fo be continued.]

IX. $O n$ 